Економічні науки: збірник наукових праџь Луцького національного технічного університету. Серія "Регіональна економіка". Випуск 17 (67). Редкол.: відп. ред. к.е.н., професор І.В. Кривов’язюк. Луцьк: ІВВ Луцького НТУ, 2020. 348 с.

УДК 332.2

Потьомкіна О.В., к.е.н., доцент

Косінський П.М., асистент кафедри економіки

Луцький національний технічний університет

\title{
СТИМУЛЮВАННЯ ВИРОБНИЦТВА БІОГАЗУ В РЕГІОНІ 3 ВІДХОДІВ ТВАРИННИЦТВА
}

У статті розглядаються питання стосовно створення та розвитку у Волинській області виробництв із переробки відходів тваринництва у біогаз. Проведено розрахунки можливих обсягів та прогнозів виробництва біогазу 3 відходів тваринництва у Волинській області. Сформовано відповідні висновки стосовно доцільності створення та розвитку виробництв із переробки відходів тваринництва у регіоні на біогаз.

Ключові слова: переробка відходів, біогаз, відходи тваринництва, відходи сільськогосподарських тварин, економічне стимулювання.

Potemkina O., Kosinskyi P.

\section{STIMULATION OF BIOGAS PRODUCTION IN THE REGION FROM ANIMAL WASTE WASTE}

Livestock waste processing contributes to the socio-economic and environmental development of the regions of the state. The article considers the issues related to the creation and development in the Volyn region of productions for processing livestock waste into biogas. It is determined that Volyn region has a significant potential for the development of livestock waste for biogas, which will increase the environmental security of the region, strengthen its energy independence, attract additional financial assets to local and regional budgets, as well as obtain the desired financial benefits business activity. Analysis of livestock waste in the Volyn region showed that there are trends to reduce them, which is primarily due to the decrease in the number of farm animals in the region.

The authors proposed to determine the possible volumes of biogas production. In the study region, there is a tendency to reduce the number of cattle and pigs, which, in turn, reduces the potential for biogas production based on manure, as evidenced by forecasts for future periods. Therefore, it is proposed to process not only livestock waste (manure) at biogas plants, but also crop waste and other solid fuel wastes. Thus, it is proposed to use at the state, regional and local levels in the complex tools to economically stimulate the growth of livestock, the development of in-depth processing of livestock products, livestock waste into alternative energy sources.

Key words: waste processing, biogas, livestock waste, farm animal waste, economic incentives. 
Економічні науки: збірник наукових праць Луиького національного технічного університету. Серія "Регіональна економіка". Випуск 17 (67). Редкол.: відп. ред. к.е.н., професор І.В. Кривов’язюк. Луцьк: ІВВ Луцького НТУ, 2020. 348 с.

Потемкина Е.В., Косинский П.М.

\section{СТИМУЛИРОВАНИЕ ПРОИЗВОДСТВА БИОГАЗА В РЕГИОНЕ ИЗ ОТХОДОВ ЖИВОТНОВОДСТВА}

В статье рассматриваются вопросы о создании и развитии в Волынской области производств по переработке отходов животноводства в биогаз. Проведены расчеты возможных объемов и прогнозов производства биогаза из отходов животноводства в Волынской области. Сформированы соответствующие выводы о целесообразности создания и развития производств по переработке отходов животноводства в регионе в биогаз.

Ключевые слова: переработка отходов, биогаз, отходы животноводства, отходы сельскохозяйственных животных, экономическое стимулирование.

Постановка проблеми у загальному її вигляді та їі зв`язок 3 важливими науковими та практичними завданнями. Практика європейських країн свідчить, що переробка (утилізація) відходів і сміття позитивно впливає не лише на екологічний стан навколишнього природного середовища, а й на покращення їх соціально-економічного розвитку.

У зв'язку з тим, що у Волинській області серед усіх видів діяльності значну частку займає сільське господарство, зокрема сфера тваринництва, відходи якої $є$ досить токсичними й шкідливими для інших природно-ресурсних об'єктів, наразі вважаємо актуальним розвивати виробництво біогазу в даному регіоні. До того ж, як стверджує відомий експерт у сфері виробництва біогазу Ю. Епштейн, «молочнотоварні, свиноферми, птахофабрики м'ясного й яєчного напряму - усі вони цілком підходять для виробництва біогазу» [1].

Аналіз останніх досліджень, у яких започатковано вирішення проблеми. Дослідженням, що стосуються переробки відходів у вітчизняних наукових джерелах приділено немало уваги. Зокрема, І.Ю. Приварникова, Ю.І. Литвиненко [2] досліджувалась суть поняття «відходи» й розглядалися можливості їх подальшої переробки. Можливості переробки сільськогосподарських відходів рослинництва та тваринництва на альтернативні види теплової й електроенергії, добрива 
Економічні науки: збірник наукових праць Луиького національного технічного університету. Серія "Регіональна економіка". Випуск 17 (67). Редкол.: відп. ред. к.е.н., професор І.В. Кривов'язюк. Луиьк: ІВВ Луцького НТУ, 2020. 348 с.

розглядали О.В. Шеліманова, А.В. Ляшенко, В.В. Михалевич, Н.С. Корбут, В.Г. Стецюк [3]. Такими науковцями, як Т.В. Ткаченко, В.О. Свдокименко, Д.С. Каменських, М.М. Філоненко, В.В. Вахрін, В.I. Кашковський [4] проводилась робота над розробкою технології безвідходного виробництва відходів рослинництва. Широке коло вчених, зокрема, Г.М. Калетнік, Н.Г. Здирко, В.Ю. Фабіянська [5], Т.В. Дикун, Л.І. Гаєва, Я.М. Дем’янчук, Т.Й. Войцехівська, Я.А. Гуцуляк [6], займалися вивченням можливостей та перспектив виробництва біогазу на основі відходів сільського господарства. Проте, мало вивченим $\epsilon$ питання можливості та доцільності розвитку виробництв біогазу на основі відходів сільськогосподарських тварин в окремих регіонах України.

Цілі статті: здійснити аналіз потенціалу та зробити відповідні висновки про доцільність виробництва біогазу у Волинській області з відходів сільськогосподарських тварин.

Викладення основного матеріалу досліджень 3 повним обгрунтуванням отриманих наукових результатів.

Створення та розвиток у Волинській області виробництв iз переробки відходів сільськогосподарських тварин, а саме гною великої рогатої худоби, свиней та пташиного посліду, на біогаз, дасть змогу:

- підвищити рівень екологічної безпеки регіону зменшить негативний зовнішній вплив на навколишнє природне середовище (сприятиме очищенню повітря, вод, грунтів на певних територіях від гнойових стоків);

- вкладати бюджетні кошти в розвиток не очисних споруд, а розвиток утилізації даних відходів, іншими словами, в їх переробку на альтернативні види енергії, що, в свою чергу, дасть змогу підвищити рівень енергонезалежності регіону;

- отримати додатковий позитивний економічний ефект, внаслідок збільшення ланцюга доданої вартості відповідних відходів, що сприятиме залученню додаткових фінансових активів в місцевий та регіональний бюджети, а також отриманню бажаної фінансової вигоди суб'єктами господарської діяльності. 
Економічні науки: збірник наукових праць Луиького національного технічного університету. Серія "Регіональна економіка". Випуск 17 (67). Редкол.: відп. ред. к.е.н., професор І.В. Кривов’язюк. Луцьк: ІВВ Луцького НТУ, 2020. 348 с.

Як стверджують Т.В. Дикун, Л.І. Гаєва та інші [6], «отримання біогазу на сьогоднішній день $є$ найбільш екологічним, простим і економічно вигідним методом утилізації відходів».

У зв'язку з вище наведеною інформацією, авторами було запропоновано визначити можливі обсяги виробництва біогазу 3 відходів (гною) сільськогосподарських тварин i, таким чином, зробити відповідні висновки про доцільність створення та розвитку комплексних виробництв із виробництва біогазу на базі відходів тваринництва у Волинській області.

Г.М. Калетнік, Н.Г. Здирко, В.Ю. Фабіянська [5] стверджують, що «вихід метану 3 гною свинячого становить $0,54 \mathrm{~m}^{3} / \kappa г, 3$ гною ВРХ - 0,28 $\mathrm{m}^{3} / \kappa г, 3$ пташиного посліду $0,41 \mathrm{~m}^{3} / \kappa г$, а в абсолютних величинах добовий вихід екскрементів від однієї голови корови сягає 40-55 кг, однієї свині - 8-10 кг, від кожних 100 голів птахів - 25 кг».

Аналіз обсягів відходів сільськогосподарських тварин у Волинській області показав, що наявні тенденції до їх зменшення (табл. 1), що, в першу чергу, пояснюється зменшенням, впродовж 2020-2019 рр., кількості сільськогосподарських тварин у регіоні. За даний період, кількість свиней зменшилась на 22,3\%, а свиней на $12,0 \%$.

Таблиця 1

Динаміка зміни кількості сільськогосподарських тварин та можливих обсягів їх відходів у Волинській області впродовж 2010-2019 pp.

\begin{tabular}{|c|c|c|c|c|c|c|c|c|}
\hline \multirow{2}{*}{$\begin{array}{c}\text { Види } \\
\text { тварин }\end{array}$} & \multicolumn{6}{|c|}{ Роки } & \multicolumn{2}{|c|}{$\begin{array}{c}\text { Відхилення, } \\
\%\end{array}$} \\
\hline & 2010 & 2015 & 2016 & 2017 & 2018 & 2019 & $\begin{array}{l}2019 / \\
2015 \\
\end{array}$ & $\begin{array}{l}2019 / \\
2010\end{array}$ \\
\hline \multicolumn{9}{|c|}{ Кількість сільськогосподарських тварин, тис. голів } \\
\hline $\mathrm{BPX}^{\mathrm{T}}$ & 191,4 & 156,8 & 152,8 & 138,3 & 130,3 & 121,8 & $-18,1$ & $-22,3$ \\
\hline Свині & 330,5 & 307,1 & 316,5 & 315,5 & 285,9 & 270,4 & $-7,1$ & $-12,0$ \\
\hline Птиця & 5513,3 & 7538,3 & 7927,8 & 7844,1 & 7560,1 & 7759,5 & 36,7 & 2,9 \\
\hline \multicolumn{9}{|c|}{ Обсяги відходів сільськогосподарських тварин (гною), тис. кг } \\
\hline $\mathrm{BPX}^{\mathrm{T}}$ & 8421,6 & 6899,2 & 6723,2 & 6085,2 & 5733,2 & 5359,2 & $-18,1$ & $-36,4$ \\
\hline Свині & 2644,0 & 2456,8 & 2532,0 & 2524,0 & 2287,2 & 2163,2 & $-7,1$ & $-18,2$ \\
\hline
\end{tabular}


Економічні науки: збірник наукових праиь Луиького національного технічного університету. Серія "Регіональна економіка". Випуск 17 (67). Редкол.: відп. ред. к.е.н., професор І.В. Кривов’язюк. Луцьк: ІВВ Луцького НТУ, 2020. 348 с.

Продовження таблиці 1

\begin{tabular}{|l|c|c|c|c|c|c|c|c|}
\hline Птиця & 1378,3 & 1884,6 & 1982,0 & 1961,0 & 1890,0 & 1939,9 & 36,7 & 40,7 \\
\hline Всього & 12443,9 & 11240,6 & 11237,2 & 10570,2 & 9910,4 & 9462,3 & $-9,7$ & $-24,0$ \\
\hline
\end{tabular}

ВРХ - велика рогата худоба.

Примітка. Сформовано автором на основі джерел: [5; 7].

На основі проведеного аналізу було здійснено підрахунок можливих обсягів виробництва біогазу в досліджуваному регіоні та, згідно наявних тенденцій, здійснено прогноз можливих обсягів виробництва біогазу (табл. 2).

Таблиця 2

Можливі обсяги та прогнозні показники виробництва біогазу 3 відходів (гною) сільськогосподарських тварин у Волинській області

(muc. $\left.\mathrm{M}^{3}\right)$

\begin{tabular}{|l|c|c|c|c|c|c|c|c|}
\hline \multirow{2}{*}{$\begin{array}{c}\text { Види } \\
\text { тварин }\end{array}$} & \multicolumn{9}{|c|}{ Роки } & \multicolumn{2}{|c|}{$\begin{array}{c}\text { Прогнозний } \\
\text { Показник }\end{array}$} \\
\cline { 2 - 10 } & 2010 & 2015 & 2016 & 2017 & 2018 & 2019 & 2024 & 2029 \\
\hline $\begin{array}{l}\text { Велика } \\
\text { рогата } \\
\text { худоба }\end{array}$ & 2358,0 & 1931,8 & 1882,5 & 1703,9 & 1605,3 & 1500,6 & 1229,3 & 954,9 \\
\hline Свині & 1427,8 & 1326,7 & 1367,3 & 1363,0 & 1235,1 & 1168,1 & 1085,4 & 955,7 \\
\hline Птиця & 565,1 & 772,7 & 812,6 & 804,0 & 774,9 & 795,3 & 1087,5 & 1119,4 \\
\hline Всього & 4350,9 & 4031,1 & 4062,4 & 3870,8 & 3615,3 & 3464,1 & 3209,4 & 2758,0 \\
\hline
\end{tabular}

Примітка. Сформовано автором на основі джерел: [5; 7].

Як видно з даних таблиці 2, у 2019 році у Волинській області можна було б виробити 3464,1 тис. м ${ }^{3}$ біогазу з відходів (гною) сільськогосподарських тварин, що становить $0,9 \%$ від річного використання природного газу в даному регіоні. Прогнози виробництва біогазу у подальшій перспективі $\epsilon$ невтішними, так як свідчать, що у 2024 році біогазу можна буде виробити на 254,7 тис. м ${ }^{3}$ менше, ніж в 2019 році, а в 2029 роціна 706,1 тис. м³.

Висновки. Виробництво біогазу з відходів (гною) сільськогосподарських тварин у Волинській області може призвести до позитивних екологічних та економічних наслідків. Зокрема, важливою перевагою може стати поселення 
Економічні науки: збірник наукових праць Луиького національного технічного університету. Серія "Регіональна економіка". Випуск 17 (67). Редкол.: відп. ред. к.е.н., професор І.В. Кривов'язюк. Луиьк: ІВВ Луцького НТУ, 2020. 348 с.

енергонезалежності даного регіону. Однак, у зв'язку з тим, що в регіоні очевидні тенденції до зменшення кількості великої рогатої худоби та свиней, то зменшується потенціал виробництва біогазу на основі їхніх відходів (гною) про, що також свідчать прогнози на майбутні періоди. Проте, якщо на біогазових заводах (станціях) переробляти не лише відходи тваринництва (гній), а й скажімо відходи рослинництва, інші твердопаливні відходи, то це може стати дуже привабливою справою, в еколого-економічному плані, для розвитку регіону. Тому державні, регіональні й місцеві органи влади повинні підібрати відповідний інструментарій економічного стимулювання розвитку тваринництва у Волинській області й інших (схожих) регіонах, а також використовувати інструменти економічного стимулювання переробки сільськогосподарської продукції й відходів сфери тваринництва, відходів (гною, екскрементів) сільськогосподарських тварин.

\section{Список бібліографічного опису}

1. Петренко І., Юрій Епштейн: «Для біогазу можливостей чимало. Агробізнес Сьогодні. 2018. № 17 (384). С. 76-77.

2. Приварникова І.Ю., Литвиненко Ю.І. Переробка та використання відходів як шлях до ресурсозбереження. Вісник Хмельницького національного університету. 2013. №4. Т. 1. С. 260-266.

3. Шеліманова О.В., ЛяшенкоА.В., Михалевич В.В., Корбут Н.С., Стецюк В.Г. Комплексна переробка відходів сільського господарства 3 виробництвом енергоносія, органічних та органомінеральних гранульованих добрив. Науковий вісник Національного університету біоресурсів $i$ природокористування Украӥни. Серія : Техніка та енергетика АПК. 2016. Вип. 256. C. $191-199$.

4. Ткаченко Т.В., Свдокименко В.О., Каменських Д.С., Філоненко М.М., Вахрін В.В., Кашковський В.І. Переробка рослинних відходів різного походження. Наука та інновачіï. 2018. № 2. С. 51-66.

5. Калетнік Г.М., Здирко Н.Г, Фабіянська В.Ю. Біогаз в домогосподарствах - запорука енергонезалежності сільських територій України. Економіка. фінанси. менеджмент: актуальні питання науки $i$ практики. 2018. № 8. С. 7-22.

6. Дикун Т.В., Гаєва Л.І., Дем'янчук Я.М., Войцехівська Т.Й., Гуцуляк Я.А. Біогаз із відходів на сміттєзвалищах як автомобільне паливо. Нафтогазова енергетика. 2018. № 1 (129). С. 56-60.

7. Статистичний щорічник Волинь 2018 / за ред. В.Ю. Науменка. Луцьк : Головне управління статистики у Волинській області, 2020. 454 с. 
Економічні науки: збірник наукових праць Луиького національного технічного університету. Серія "Регіональна економіка". Випуск 17 (67). Редкол.: відп. ред. к.е.н., професор І.В. Кривов’язюк. Луцьк: ІВВ Луцького НТУ, 2020. 348 с.

\section{References}

1. Petrenko I. Yuriy Epshteyn: Dlya biohazu mozhlyvostey chymalo Ahrobiznes S'ohodni, 2018, no 17, pp. 76-77 [in Ukrainian].

2. Pryvarnykova I.Yu., Lytvynenko Yu.I. Pererobka ta vykorystannya vidkhodiv yak shlyakh do resursozberezhennya - Visnyk Khmel'nyts'koho natsional'noho universytetu, 2013 no. 4, pp. 260-266 [in Ukrainian].

3. Shelimanova O.V., Lyashenko A.V., Mykhalevych V.V., Korbut N.S., Stetsyuk V.H. Kompleksna pererobka vidkhodiv sil's'koho hospodarstva z vyrobnytstvom enerhonosiya, orhanichnykh ta orhanomineral'nykh hranul'ovanykh dobryv - Naukovyy visnyk Natsional'noho universytetu bioresursiv i pryrodokorystuvannya Ukrayiny. Seriya : Tekhnika ta enerhetyka APK, 2016, no 256, pp. 191-199 [in Ukrainian].

4. Tkachenko T.V., Yevdokymenko V.O., Kamens'kykh D.S., Filonenko M.M., Vakhrin V.V., Kashkovs'kyy V.I. Pererobka roslynnykh vidkhodiv riznoho pokhodzhennya - Nauka ta innovatsiyi, 2018, no 2, pp. 51-66 [in Ukrainian].

5. Kaletnik H.M., Zdyrko N.H, Fabiyans'ka V.Yu. Biohaz v domohospodarstvakh - zaporuka enerhonezalezhnosti sil's'kykh terytoriy Ukrayiny - Ekonomika. finansy. menedzhment: aktual'ni pytannya nauky i praktyky, 2018, no 8, pp. 7-22 [in Ukrainian].

6. Dykun T.V., Hayeva L.I., Dem"yanchuk Ya.M., Voytsekhivs'ka T.Y., Hutsulyak Ya. A. Biohaz iz vidkhodiv na smittyezvalyshchakh yak avtomobil'ne palyvo - Naftohazova enerhetyka,. 2018, no1, pp. 56-60 [in Ukrainian].

7. Naumenko V. Yu. Statystychnyy shchorichnyk Volyn' 2018. Luts'k, Holovne upravlinnya statystyky u Volyns'kiy oblasti, 2020. 454 p. [in Ukrainian]. 